\title{
Improvement of Qualitative and Quantitative Traits of Autumn Season Specific Lines/Breeds for Temperate Climatic Conditions of Jammu and Kashmir
}

\author{
Shivkumar $^{1 *}$, Bharath Kumar Neelaboina ${ }^{2}$, Mir Nisar Ahmad ${ }^{3}$, Kiran R $^{4}$, S Roy Chowdhury ${ }^{5}$ \\ ${ }^{1}$ Scientist C, Silkworm Breeding and Genetics Laboratory, CSR\&TI, Central Silk Board, Pampore-192121 Jammu and \\ Kashmir, India \\ ${ }^{2}$ Scientist C, Silkworm Breeding and Genetics Laboratory, CSR\&TI, Central Silk Board, Pampore-192121 Jammu and \\ Kashmir, India \\ ${ }^{3}$ Scientist D, Silkworm Breeding and Genetics Laboratory, CSR\&TI, Central Silk Board, Pampore-192121 Jammu and \\ Kashmir, India \\ ${ }^{4}$ Scientist B, Silkworm Breeding and Genetics Laboratory, CSR\&TI, Central Silk Board, Pampore-192121 Jammu and \\ Kashmir, India \\ ${ }^{5}$ Director, CSR\&TI, Central Silk Board, Pampore-192121 Jammu and Kashmir, India
}

*Address for Correspondence: Dr. Shivkumar, Scientist C, Silkworm Breeding and Genetics Laboratory, CSR\&TI, Central Silk Board, Pampore-192121 Jammu and Kashmir, India

E-mail: shivabsajjan@gmail.com

Received: 22 May 2020/ Revised: 24 Aug 2020/ Accepted: 29 Oct 2020

\begin{abstract}
Background: The present study having relevance to the improvement of qualitative and quantitative traits by utilizing eighteen (18) autumn specific lines (ASL) of F9 generation with SH6 $\times$ NB4D2 as control.

Methods: Total 18 ASL were incubated and reared as per the standard rearing procedures to understand their suitability and data was recorded for the targeted economic traits viz., Fec. (no.), h(\%), yield by no. and wt. (kg)/10,000 larvae brushed, SCW (g), SSW (g), SR (\%), PR(\%) and FL(m).

Results: The data obtained in regards to rearing performance revealed that, among all the lines, the higher SR of $21.38 \%$ was recorded in line-3 and greater FL of $990(\mathrm{~m})$ was also observed in the same line. For the trait, PR was found $>90$ in all the ASL and highest of 96 exhibited in line-5. Hence, an increase of traits observed viz., fec.(no.), h(\%), SCW(g), SSW(g), SR(\%), FL (m) and PR(\%) were noticed with an increase of 45no., 4.02\%, $0.09 \mathrm{~g}, 0.04 \mathrm{~g}, 1.99 \%, 240 \mathrm{~m}$ and 2\%, respectively over the control (SH6 $\times$ NB4D2). The data obtained was subjected to the multiple trait El (Evaluation Index) and results clearly showed that, out of 18 lines under study, eight lines viz.,1, 5, 6, 7, 9, 16, 17, and 18 have shown higher index values $(>50)$ and influenced significantly on the improvement of traits over the control and have economically importance.

Conclusion: Lines identified from the study can conveniently be utilized for developing high yielding autumn specific bivoltine hybrids and can be used for commercial exploitation at farmer's level during the autumn season in the temperate region of Jammu and Kashmir.
\end{abstract}

Key-words: Autumn specific lines, Bombyx mori L, El, Kashmir valley, Temperate climate, Qualitative and Quantitative traits

\section{INTRODUCTION}

Jammu and Kashmir is a traditional sericulture state, which enjoys temperate climate congenial for bivoltine

How to cite this article

Kumar S, Neelaboina BK, Ahmad MN, Kiran R, Chowdhury SR. Improvement of Qualitative and Quantitative Traits of Autumn Season Specific Lines/Breeds for Temperate Climatic Conditions of Jammu and Kashmir. SSR Inst. Int. J. Life Sci., 2020; 6(6): 27172725.

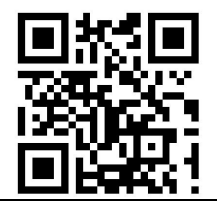

silkworms rearing during the spring season (April-May) and bivoltine silkworm races are primarily suited for temperate climatic conditions of Jammu and Kashmir. The commercial rearing in Kashmir is mainly conducted during the spring season and only $10-15 \%$ farmers' conduct second rearing during the summer season by Sahaf et al. ${ }^{[1]}$. Till date, the limited number of silkworm breeds/ hybrids has been developed for the spring season under temperate climatic conditions of Kashmir by Trag et al. ${ }^{[2]}$, Kamili et al. ${ }^{[3]}$, Malik et al. ${ }^{[4]}$ and Malik et 
al. ${ }^{[5]}$. Few attempts have also been made for identification of hybrids for summer or autumn season by Farooq et al. ${ }^{[6]}$, Malik et al. ${ }^{[7]}$ and Mir Nisar et al. ${ }^{[8]}$. The cocoon productivity has been reported as $30-40$ $\mathrm{kg} / 100 \mathrm{dfls}$ in spring crop and $20-25 \mathrm{~kg} / 100 \mathrm{dfls}$ in autumn crop by Chauhan et al. ${ }^{[9]}$.

The univoltines and bivoltines are known for better quantitative characters with quality silk but they are sensitive to environmental and dietary stress. The exploitation of heterosis through single hybrids in silkworms for economic traits triggered a revolutionary change in overall qualitative and quantitative silk output ${ }^{[10]}$. It has demonstrated the superiority of single, threeway and double hybrids over their parental races ${ }^{[11]}$. Utilization of hybrid vigour for development of new genotypes was introduced in $1901^{[12]}$ and with this strategy, different races were crossed to utilize their hybrid vigour and variation as a tool to develop new genotypes. Although survival could be maintained in single hybrids they are handicapped by less number of eggs laid by inbred pure mother moth. Unless the mother moth is a hybrid, the fecundity cannot be increased ${ }^{[13]}$. It advocated the repeated backcrossing method for the improvement of cocoon quality ${ }^{[14]}$ and few attempts were also made in India for the success of autumn crop at the temperate zone of Kashmir by Malik et al. ${ }^{[5]}$, Farooq et al. ${ }^{[6]}$ and Malik et al. ${ }^{[7]}$.

Breeding for autumn specific silkworm genotypes for temperate climatic conditions remained a challenge before silkworm breeders in North-West India and autumn rearing are entailed with high temperature and high humidity at the initial stage of silkworm rearing. Higher pathogen load and inferior quality of mulberry leaf at farmers' field also affect the crop under temperate conditions, although the temperature is not high, yet the production is far below the spring average due to poor quality of mulberry leaf and non-availability of potential autumn specific breeds and hybrids. Hence, present research work is focused on the improvement of qualitative and quantitative traits as a phase-wise manner and at the end of the programme; it is the main target to evolving autumn specific bivoltine breeds and hybrids during the autumn season in the temperate region of Jammu and Kashmir.

\section{MATERIALS AND METHODS}

The present study proceeded from April 2019 to June 2019 in the Silkworm Breeding and Genetics Laboratory,
Central Sericultural Research and Training Institute (CSR\&TI), Central Silk Board, Pampore-192121 Jammu and Kashmir, India.

Selection of parentages for the study- Parental seed of the above said line's races/breeds were collected from the Germplasm Bank of Central Sericultural Research and Training Institute (CSR\&TI), Mysore (CSR2, CSR26, CSR27, CSR50, and CSR52), Andhra Pradesh State Sericulture Research and Development Institute, Hindupur, Andhra Pradesh (APS4, APS5 and APS9) and CSR\&TI, Pampore (Pam101 and Pam117) along with control (SH6 and $\mathrm{NB}_{4} \mathrm{D}_{2}$ ).

Crossing and location of study- The crossing of collected parental material was carried out with different combination in the Silkworm Breeding and Genetics laboratory of CSR\&TI, Pampore during spring season 2016 and eighteen (18) autumn specific lines (ASL) of F9 generations comprising different combinations of bivoltine silkworm Bombyx mori (B. mori) were selected for the present investigation.

Methods Adopted- The eighteen lines of F9 generation were incubated and reared during spring, 2019 along with a control $\left(\mathrm{SH}_{6} \times \mathrm{NB}_{4} \mathrm{D}_{2}\right)$ by adopting the methods described by Tazima [14] and Krishnaswami ${ }^{[15]}$, respectively.

Silkworm rearing and target traits for data analysis- The silkworm larvae were fed with suitable quality mulberry leaves for both young (Ichinose and KNG) and late age (Goshoerami). For assessing the comparative performance of the eighteen lines of F9 generation along with control was done for targeted traits such as fecundity no. (Fec. no.), hatching percentage (h\%), larval duration (days) yield by number/10,000 larvae brushed (no.), yield by weight/ 10,000 larvae brushed (kg), single cocoon weight ( $\mathrm{SCWg}$ ), single shell weight ( $\mathrm{SSWg}$ ), shell ratio (SR\%), pupation rate (PR\%) and filament length (FL.m).

Statistical Analysis- The data generated were subjected to multi-traits evaluation Index method developed by Mano et al. ${ }^{[16]}$ as per the formula details given below.

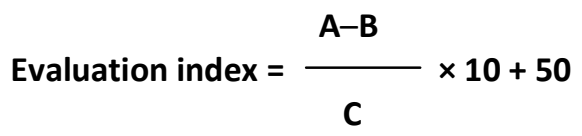


Where,

A: Value obtained for a particular trait of a particular line

B: Mean value of particular trait of all the particular lines

The index value obtained as described above was estimated for each of the traits analyzed. Further, the indices obtained for all the traits were combined to get a single value, which is the average E.I. The average index value fixed for the selection of a line was $>50$. The index values of lines which are relatively higher than 50 are considered as greater economic value.

\section{RESULTS}

Target characters for the experiment- The results regarding the rearing performance of selected traits of 18 autumn specific breeding lines along with a control (SH6 $\times$ NB4D2) at F9 generation during spring 2019 were
C: Standard Deviation of a particular trait of all the particular lines

10: Standard Unit and 50: Fixed Value

reared at Silkworm Breeding and Genetics Section of CSR\&TI, Pampore, Jammu and Kashmir by recording the traits viz., Fecundity (No,), Hatching \%, Yield /10,000 larvae by no. and by weight $(\mathrm{kg})$, Single cocoon weight (g), Single shell weight (g), Shell ratio (\%), Pupation rate (\%) and Filament length $(\mathrm{m})$ along with statistical analysis of multi- traits evaluation index values.

Rearing performance of autumn specific lines at F9 generation- The perusal of data in regards to the rearing performance of 18 autumn specific breeding lines along with a control $(\mathrm{SH} 6 \times \mathrm{NB} 4 \mathrm{D} 2)$ at F9 generation during spring 2019 (Table 1).

Table 1: Rearing performance of selected traits of 18 autumn specific lines along with a control (SH6×NB4D2) of bivoltine silkworm at F9 generation of silkworm B. mori L.

\begin{tabular}{|c|c|c|c|c|c|c|c|c|c|}
\hline \multirow{2}{*}{$\begin{array}{l}\text { Traits } \\
\text { Lines }\end{array}$} & \multirow{2}{*}{$\begin{array}{l}\text { Fecundity } \\
\text { (no.) }\end{array}$} & \multirow{2}{*}{$\begin{array}{c}\text { Hatching } \\
\text { (\%) }\end{array}$} & \multicolumn{2}{|c|}{$\begin{array}{c}\text { Yield/10,000 } \\
\text { Larvae }\end{array}$} & \multirow{2}{*}{$\begin{array}{l}\text { Single } \\
\text { Cocoon } \\
\text { Wt (g) }\end{array}$} & \multirow{2}{*}{$\begin{array}{l}\text { Single Shell } \\
\text { Weight (g) }\end{array}$} & \multirow{2}{*}{$\begin{array}{c}\text { Shell Ratio } \\
\text { (\%) }\end{array}$} & \multirow{2}{*}{$\begin{array}{c}\text { Pupation } \\
\text { Rate } \\
\text { (\%) }\end{array}$} & \multirow{2}{*}{$\begin{array}{l}\text { Filament } \\
\text { Length }(\mathrm{m})\end{array}$} \\
\hline & & & By no. & By wt (kg) & & & & & \\
\hline Line-1 & 444 & 94.14 & 9560 & 15.80 & 1.84 & 0.38 & 20.42 & 92 & 751 \\
\hline Line -2 & 519 & 95.91 & 9560 & 13.52 & 1.60 & 0.31 & 19.48 & 94 & 853 \\
\hline Line -3 & 511 & 95.69 & 9560 & 12.64 & 1.51 & 0.32 & 21.38 & 94 & 990 \\
\hline Line -4 & 569 & 95.86 & 9100 & 13.16 & 1.81 & 0.35 & 19.06 & 93 & 865 \\
\hline Line -5 & 565 & 95.15 & 9780 & 14.02 & 1.62 & 0.33 & 20.44 & 96 & 870 \\
\hline Line -6 & 552 & 95.31 & 9280 & 14.41 & 1.75 & 0.34 & 19.39 & 94 & 972 \\
\hline Line -7 & 510 & 95.47 & 9860 & 15.60 & 1.77 & 0.35 & 20.00 & 94 & 908 \\
\hline Line -9 & 599 & 95.90 & 9740 & 15.25 & 1.75 & 0.35 & 20.11 & 95 & 881 \\
\hline Line -11 & 603 & 95.69 & 9240 & 13.36 & 1.65 & 0.33 & 19.85 & 91 & 758 \\
\hline Line -12 & 585 & 95.50 & 9460 & 13.85 & 1.65 & 0.30 & 18.08 & 92 & 693 \\
\hline Line -14 & 493 & 95.36 & 9760 & 13.89 & 1.61 & 0.33 & 20.62 & 93 & 820 \\
\hline Line -15 & 607 & 96.05 & 9500 & 13.68 & 1.63 & 0.31 & 19.24 & 93 & 718 \\
\hline Line -16 & 531 & 99.52 & 9460 & 13.90 & 1.66 & 0.32 & 19.17 & 92 & 955 \\
\hline Line -17 & 564 & 95.18 & 9820 & 13.63 & 1.57 & 0.32 & 20.55 & 95 & 971 \\
\hline Line -18 & 572 & 95.20 & 9740 & 15.57 & 1.78 & 0.35 & 19.69 & 95 & 882 \\
\hline Line -19 & 591 & 95.74 & 9240 & 14.63 & 1.78 & 0.32 & 18.22 & 91 & 815 \\
\hline Line -21 & 485 & 94.96 & 9180 & 14.61 & 1.79 & 0.33 & 18.40 & 91 & 778 \\
\hline Line -24 & 498 & 94.98 & 9540 & 14.41 & 1.70 & 0.32 & 18.95 & 93 & 728 \\
\hline $\begin{array}{c}\text { Control } \\
\text { (SH6×NB4D2) }\end{array}$ & 562 & 95.50 & 9280 & 14.41 & 1.75 & 0.34 & 19.39 & 94 & 750 \\
\hline Ranges & $444-607$ & $\begin{array}{l}94.96- \\
99.52\end{array}$ & $\begin{array}{l}9100- \\
9820\end{array}$ & $\begin{array}{l}13.36- \\
15.80\end{array}$ & $1.51-1.84$ & $0.30-0.38$ & $\begin{array}{l}18.08- \\
21.38\end{array}$ & $91-96$ & $693-990$ \\
\hline Average & 545 & 95.64 & 9508 & 14.23 & 1.70 & 0.33 & 19.60 & 93.26 & 839.89 \\
\hline
\end{tabular}


Crossef DOI: $10.21276 /$ SSR-IIJLS.2020.6.6.7

$\begin{array}{llllllllll}\text { Std Dev. } & 46.07 & 1.04 & 235.9 & 0.87 & 0.09 & 0.02 & 0.87 & 1.48 & 93.31\end{array}$

INDEX: Line-1 (Pamp101 × CSR2), Line -2 (Pamp101 × CSR26), Line -3 (Pamp101 × CSR27), Line -4 (Pamp101 × CSR50), Line -5 (Pamp101 $\times$ CSR52), Line -6 (Pamp117 × CSR2), Line -7 (Pamp117X × CSR26), Line -9 (Pamp117 × CSR50), Line -11 (APS4 $\times$ CSR2), Line -12 (APS4 $\times$ CSR26), Line -14 (APS4 × CSR50), Line -15 (APS4 $\times$ CSR52), Line -16 (APS5 $\times$ CSR2), Line -17 (APS5 × CSR26), Line -18 (APS5 $\times$ CSR27), Line -19 (APS5 $\times$ CSR50), Line -21 (APS9 $\times$ CSR2), Line -24 (APS9 $\times$ CSR50) and Control (SH6 × NB4D2).

The trait regarding fecundity revealed that the highest fecundity 607 (no.) was observed in line-15 and followed by 603 in line11among all the lines and a lowest of 444 (no.) was recorded in line-1. The trait hatching percentage was observed maximum of $99.52 \%$ in line-16 and a minimum percentage of 94.96 was recorded in line-21 (Fig. 1). Similarly, cocoon yield/10,000 larvae by number were maximum 9820 in line-17 and the minimum 9100 in line- 4 and yield by weight $(\mathrm{kg}) / 10,000$ larvae was maximum 15.80 in line1-18, whereas minimum 13.36 in line-11. Further, single cocoon weight (Fig. 2), Single shell weight (Fig. 3) and shell ratio (Fig. 4) were observed $1.848 \mathrm{~g}, 0.38 \mathrm{~g}$, and $21.38 \%$ were highest in line-1, line-1 and line-3 respectively. The filament length of 990 meters was recorded highest in line-3 and pupation rate was found above $90 \%$ in all lines and the maximum was $96 \%$ in line- 6 . Further, it is very interesting to know regarding the improvement of qualitative and quantitative traits among all the selected lines. The data obtained in regards to rearing performance of $\mathrm{F} 9$ generation revealed that, among all the selected eighteen breeding lines, the higher shell ratio of $21.38 \%$ was recorded in line-3 and filament length greater of $990(\mathrm{~m})$ in the same line-03. For the trait, pupation rate was found above $90 \%(>90 \%)$ in all the selected autumn specific lines and highest of $96 \%$ was exhibited in line-5.
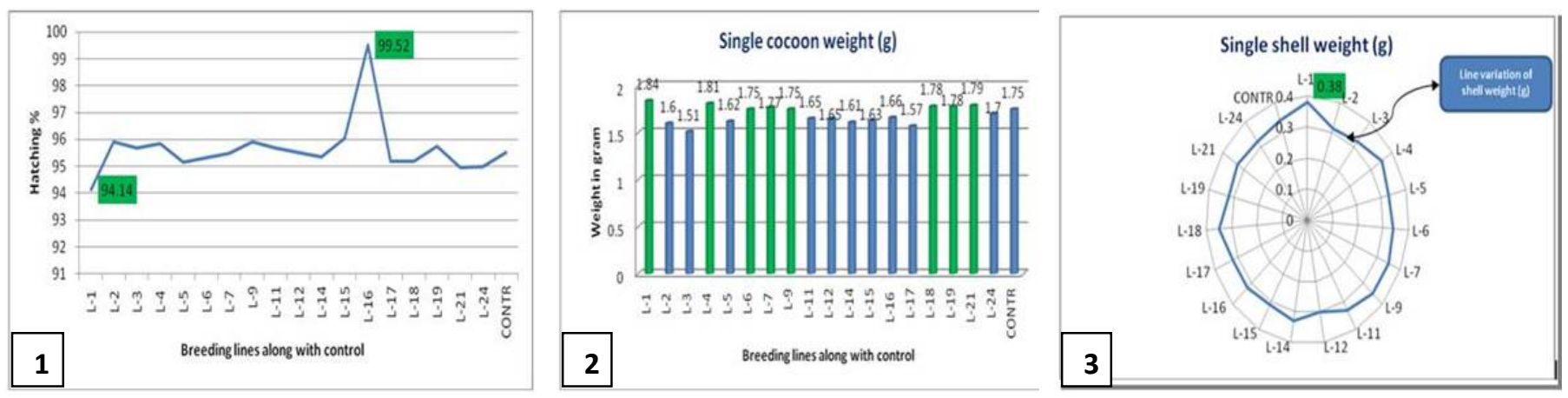

Fig. 1: Variation of hatching percentage among autumn specific breeding lines at F9 generation of the silkworm B. mori L.

Fig. 2: Single cocoon weight among autumn specific breeding lines at F9 generation of the silkworm B. mori L. Fig. 3: single shell percentage among autumn specific breeding lines at F9 generation of the silkworm $B$. mori $\mathrm{L}$.
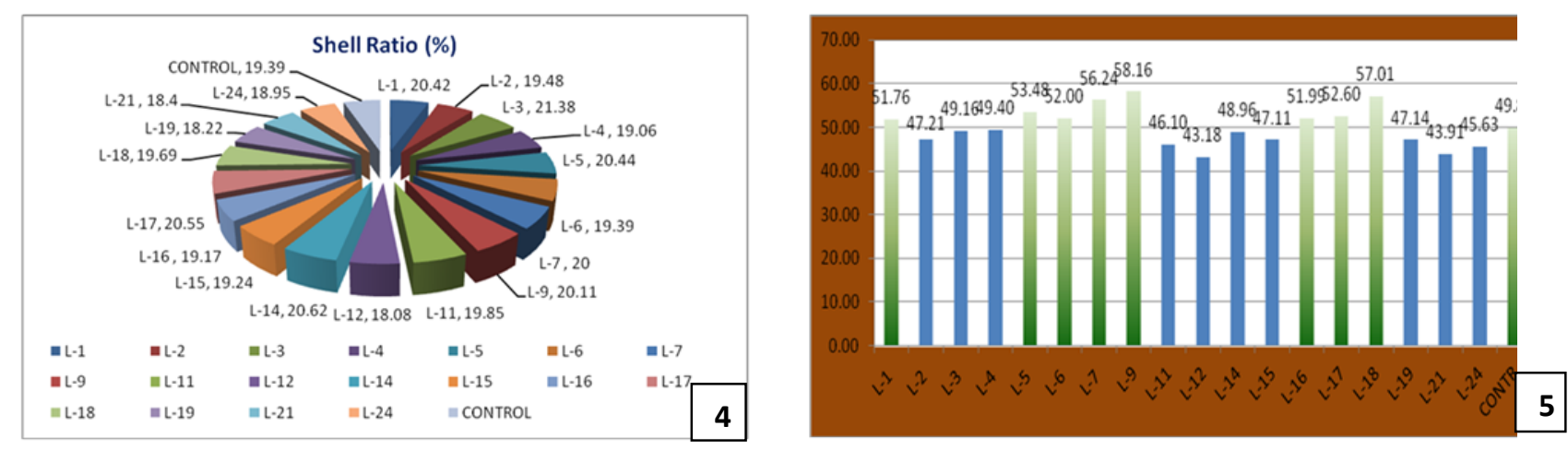

Fig. 4: Variation of shell ratio (\%) among autumn specific breeding lines at $\mathrm{F} 9$ generation of the silkworm B. mori L.

Fig. 5: Multi-traits evaluation index among autumn specific breeding lines at F9 generation of the silkworm B. mori L. 
The positive influence of qualitative and quantitative traits towards quality cocoon production- There was an increase of qualitative and quantitative traits observed viz., fecundity (no.), hatching (\%), single cocoon weight (g), single shell weight (g), shell ratio (\%), filament length (m) and pupation rate(\%) were noticed with an increase of $45 \mathrm{no} ., 4.02 \%, 0.09 \mathrm{~g}, 0.04 \mathrm{~g}, 1.99 \%, 240 \mathrm{~m}$ and $2.00 \%$ respectively over the control (SH6 $\times$ NB4D2).

Multi-traits evaluation index- The data obtained was subjected to the statistical analysis of multi- traits evaluation index of F9 generation during spring season was presented in Table 2 and the same was represented as Fig. 5. The results obtained was clearly shown, line-9 (58.16) was exhibited highest index value among all autumn specific breeding lines under study. Further, out of 18 lines under the study, there were 08 autumn specific breeding lines (line-1, line-5, line-6, line-7, line- 9 , line-16, line-17, and line-18) have recorded the $>50$ index values (Table 2 and Fig. 5), which is considered as economically viable autumn specific breeding lines. The index value along with the mean of all the traits and standard deviation are presented in the same table. Further, statistically analyzed data in regards to mean evaluation index of selected traits was given as per their rank for all the breeding lines and it was found that highest index value of 58.16 was observed in line-9 $\left(1^{\text {st }}\right.$ rank) and followed by line-18 (57.01), line-7 (56.24), line-5 (53.48), line-17 (52.60), line-6 (52.00), line-16 (51.99), line-1 (51.76), and remaining lines exhibited $<50$ index values, which is economically not viable. The details regarding photographs of larvae and cocoon of highest index values (>50) autumn specific lines along with a control (SH6 $\times$ NB4D2), which are economically viable are represented as figures with silkworm larvae (Fig. 6 to 14) and silkworm cocoons (Fig. 15 to 23).

Table 2: Multi-traits evaluation index of selected traits of 18 autumn specific lines along with a control (SH6×NB4D2) of bivoltine silkworm at F9 generation of silkworm B. mori L.

\begin{tabular}{|c|c|c|c|c|c|c|c|c|c|c|c|}
\hline \multirow{2}{*}{ Lines } & \multirow[b]{2}{*}{$\begin{array}{l}\text { Fecundity } \\
\text { (no.) }\end{array}$} & \multirow[b]{2}{*}{$\begin{array}{c}\text { Hatching } \\
\text { (\%) }\end{array}$} & \multicolumn{2}{|c|}{ Yield/10,000 } & \multirow{2}{*}{$\begin{array}{l}\text { Single } \\
\text { Cocoon } \\
\text { Wt (g) }\end{array}$} & \multirow{2}{*}{$\begin{array}{l}\text { Single } \\
\text { Shell } \\
\text { Wt (g) }\end{array}$} & \multirow{2}{*}{$\begin{array}{c}\text { Shell } \\
\text { Ratio } \\
(\%)\end{array}$} & \multirow[b]{2}{*}{$\begin{array}{l}\text { Pupation } \\
\text { Rate (\%) }\end{array}$} & \multirow{2}{*}{$\begin{array}{l}\text { Filament } \\
\text { Length } \\
\text { (m) }\end{array}$} & \multirow{2}{*}{$\begin{array}{l}\text { Mean } \\
\text { El of } \\
\text { all the } \\
\text { traits }\end{array}$} & \multirow[b]{2}{*}{$\begin{array}{l}\text { Ranking } \\
\text { of lines }\end{array}$} \\
\hline & & & $\begin{array}{l}\text { By } \\
\text { no. }\end{array}$ & $\begin{array}{l}\text { By wt. } \\
\text { (kg) }\end{array}$ & & & & & & & \\
\hline Line-1 & 28.08 & 35.58 & 52.21 & 68.05 & 65.56 & 75.00 & 59.43 & 41.49 & 40.47 & 51.76 & 8 \\
\hline Line -2 & 44.36 & 52.60 & 52.21 & 41.84 & 38.89 & 40.00 & 48.62 & 55.00 & 51.40 & 47.21 & 13 \\
\hline Line -3 & 42.62 & 50.48 & 52.21 & 31.72 & 28.89 & 45.00 & 70.46 & 55.00 & 66.09 & 49.16 & 11 \\
\hline Line -4 & 55.21 & 52.12 & 32.64 & 37.70 & 62.22 & 60.00 & 43.79 & 48.24 & 52.69 & 49.40 & 10 \\
\hline Line -5 & 54.34 & 45.29 & 61.57 & 47.59 & 41.11 & 50.00 & 59.66 & 68.51 & 53.23 & 53.48 & 4 \\
\hline Line -6 & 51.52 & 46.83 & 40.30 & 52.07 & 55.56 & 55.00 & 47.59 & 55.00 & 64.16 & 52.00 & 6 \\
\hline Line -7 & 42.40 & 48.37 & 64.98 & 65.75 & 57.78 & 60.00 & 54.60 & 55.00 & 57.30 & 56.24 & 3 \\
\hline Line -9 & 61.72 & 52.50 & 59.87 & 61.72 & 55.56 & 60.00 & 55.86 & 61.76 & 54.41 & 58.16 & 1 \\
\hline Line -11 & 62.59 & 50.48 & 38.60 & 40.00 & 44.44 & 50.00 & 52.87 & 34.73 & 41.22 & 46.10 & 16 \\
\hline Line -12 & 58.68 & 48.65 & 47.96 & 45.63 & 44.44 & 35.00 & 32.53 & 41.49 & 34.26 & 43.18 & 19 \\
\hline Line -14 & 38.71 & 47.31 & 60.72 & 46.09 & 40.00 & 50.00 & 61.72 & 48.24 & 47.87 & 48.96 & 12 \\
\hline Line -15 & 63.46 & 53.94 & 49.66 & 43.68 & 42.22 & 40.00 & 45.86 & 48.24 & 36.94 & 47.11 & 15 \\
\hline Line -16 & 46.96 & 87.31 & 47.96 & 46.21 & 45.56 & 45.00 & 45.06 & 41.49 & 62.34 & 51.99 & 7 \\
\hline Line -17 & 54.12 & 45.58 & 63.28 & 43.10 & 35.56 & 45.00 & 60.92 & 61.76 & 64.05 & 52.60 & 5 \\
\hline Line -18 & 55.86 & 45.77 & 59.87 & 65.40 & 58.89 & 60.00 & 51.03 & 61.76 & 54.51 & 57.01 & 2 \\
\hline Line -19 & 59.98 & 50.96 & 38.60 & 54.60 & 58.89 & 45.00 & 34.14 & 34.73 & 47.33 & 47.14 & 14 \\
\hline
\end{tabular}




\begin{tabular}{cccccccccccc}
\hline Line -21 & 36.98 & 43.46 & 36.04 & 54.37 & 60.00 & 50.00 & 36.21 & 34.73 & 43.37 & 43.91 & 18 \\
Line -24 & 39.80 & 43.65 & 51.36 & 52.07 & 50.00 & 45.00 & 42.53 & 48.24 & 38.01 & 45.63 & 17 \\
$\begin{array}{c}\text { Control } \\
\text { (SH6XNB4D2) }\end{array}$ & 53.69 & 48.65 & 40.30 & 52.07 & 55.56 & 55.00 & 47.59 & 55.00 & 40.37 & 49.80 & 9 \\
\hline
\end{tabular}
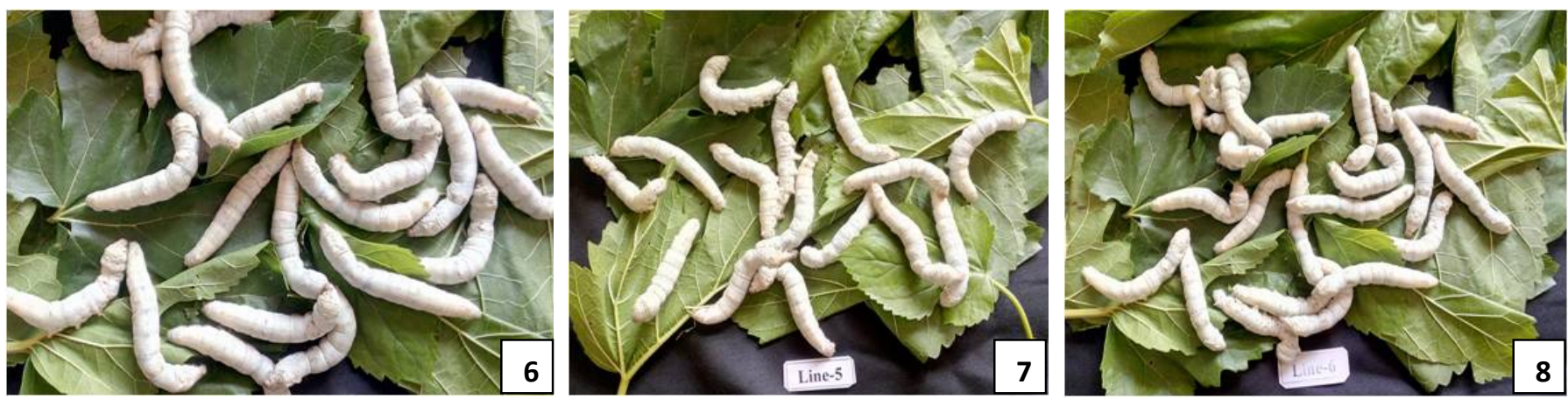

Fig. 6, 7, 8: Larvae of shortlisted lines viz., line-1, line-5 and line-6 at F9 generation of the silkworm B. mori L.
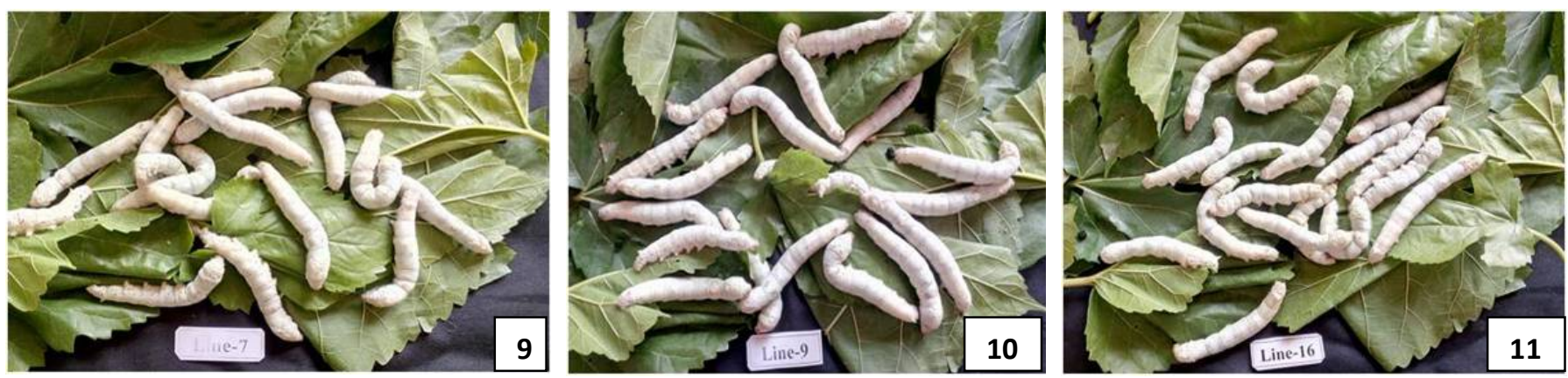

Fig. 9, 10, 11: Larvae of shortlisted lines viz., line-7, line-9 and line-16 at F9 generation of the silkworm B. mori L.
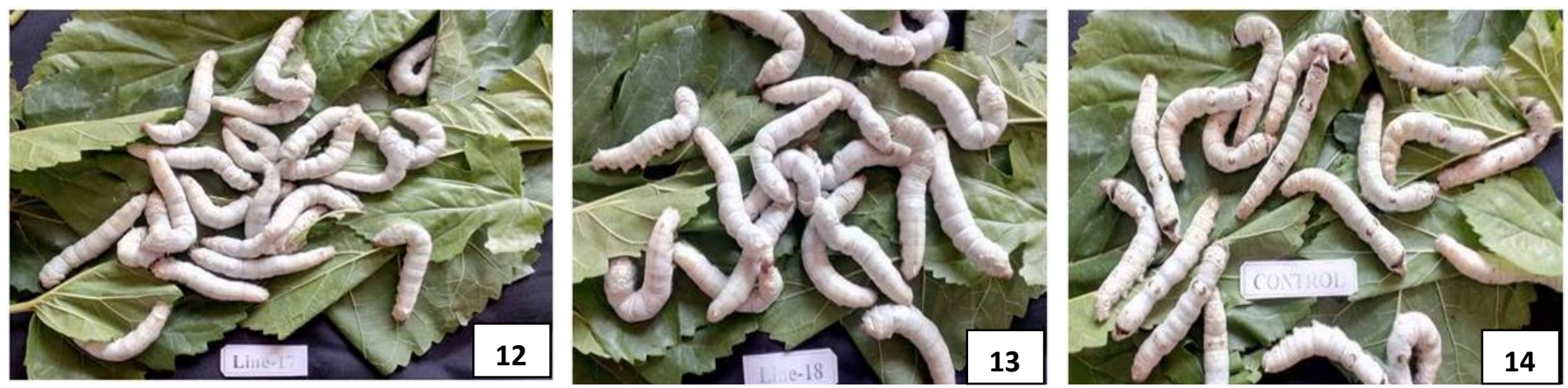

Fig.12, 13, 14: Larvae of shortlisted lines viz., line-17, line-18 and control (SH6×NB4D2) at F9 generation of the silkworm B. mori L.
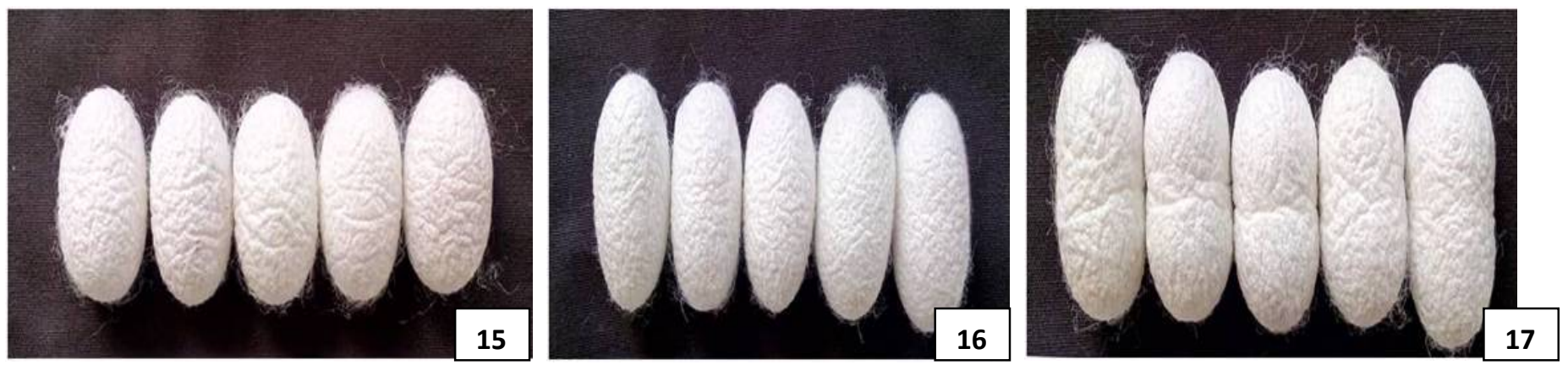

Fig.15, 16, 17: Cocoon of shortlisted lines viz., line-1, line-5 and line-6 at F9 generation of the silkworm B. mori L. 

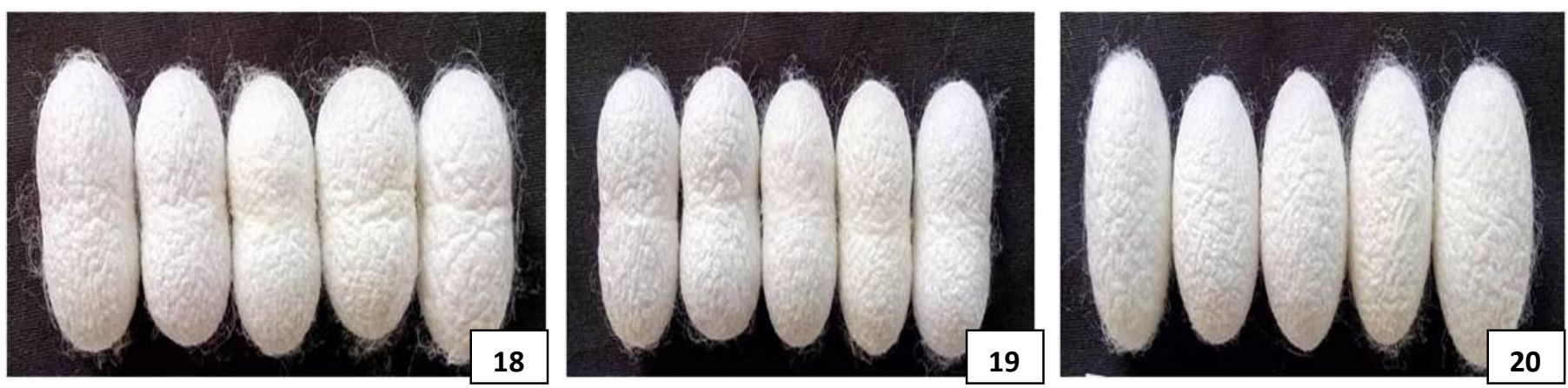

Fig. 18, 19, 20: Cocoons of shortlisted lines viz., line-7, line-9 and line-16 at F9 generation of the silkworm B. mori L.
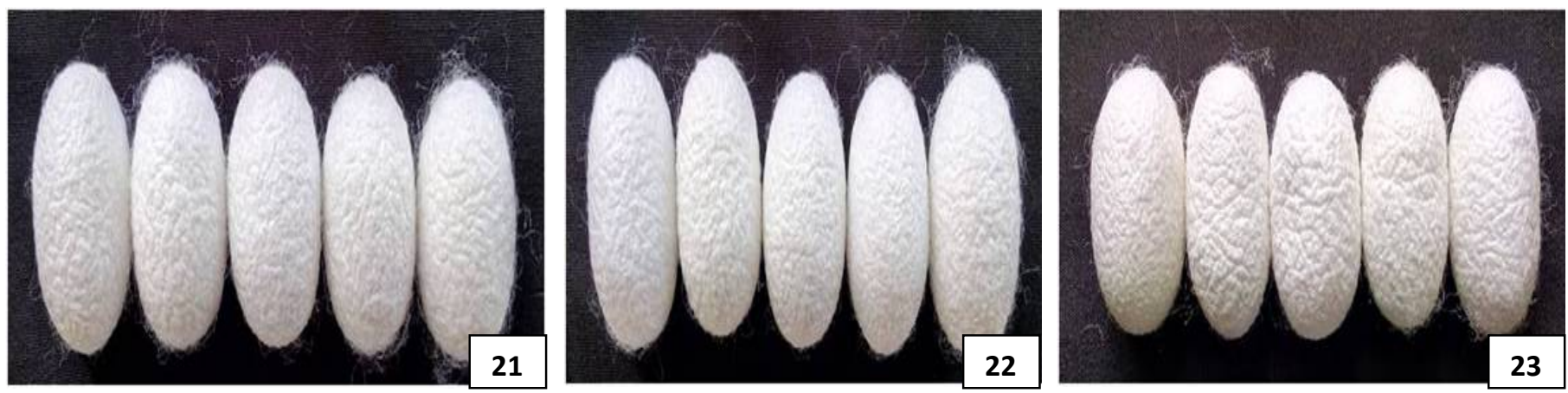

Fig. 21, 22, 23: Cocoons of shortlisted lines viz., line-17, line-18 and control (SH6×NB4D2) at F9 generation of the silkworm B. mori L.

\section{DISCUSSION}

The results from Table 1 in regards to rearing performance revealed, among all the eighteen autumn specific lines. Higher shell ratio was recorded of $21.38 \%$ in line-3 and greater filament length was also observed at $990(\mathrm{~m})$ in the same line. For the trait, pupation rate was found $>90$ in all the autumn specific lines and highest of 96 exhibited in line-5. Hence, an increase of qualitative and quantitative traits observed viz., fecundity (no.), hatching percentage (\%), single cocoon weight(g), single shell weight(g), shell ratio(\%), filament length $(\mathrm{m})$ and pupation rate(\%) was noticed with an increase of $45 \mathrm{no}$., $4.02 \%, 0.09 \mathrm{~g}, 0.04 \mathrm{~g}, 1.99 \%, 240 \mathrm{~m}$ and $2.00 \%$ respectively over the control (SH6 $\times$ NB4D2). The breeding lines, which exhibited superior performance will serve as the base material for further selection as breeding resource material and also judging superiority of traits through evaluation index (Perkins and Jink ${ }^{[17]}$, Freeman and Perkins ${ }^{[19]}$, Anantha and Subramanya ${ }^{[22]}$, Shiv and Subramanya ${ }^{[23]}$ ).

Further, data in regards to the multi-traits evaluation index of selected traits of 18 autumn specific lines along with a control (SH6×NB4D2) of bivoltine silkworm at F9 generation of silkworm B. mori L (Table 2) clearly showed that, out of 18 lines under study, eight lines viz., line-1, line-5, line-6, line-7, line-9, line- 16 , line- 17 , and line- 18 have shown higher index values $(>50)$. The results obtained under the present study slightly corroborate with the results of ${ }^{[22,23]}$. Furthermore, economic parameters influenced significantly on the improvement of traits over the control and have economically importance, which was documented by several researchers (Masrat et al. ${ }^{[24]}$, Maqbool et al. ${ }^{[25]}$ ).

The further performance of these lines not only depends on the quantitative traits but also on their adaptability under diverse environmental conditions during the autumn season in temperate climatic condition of Kashmir. Such variable performance of the races/breeds and seasonal influences on the performance of the races/ breeds/ livestock animals are very well documented by several breeders (Perkins and Jink ${ }^{[17]}$, Sengupta ${ }^{[18]}$, Freeman and Perkins ${ }^{[19]}$, Krishnaswami and Narasimhanna [20], Subramanya and Murakami [21], Anantha and Subramanya ${ }^{[22]}$, Shiv and Subramanya ${ }^{[23]}$ ). Further, several attempts were made in the temperate zone ${ }^{[2,3]}$, Malik et al. ${ }^{[4]}$, Nisar et al. ${ }^{[8]}$, Masrat et al. ${ }^{[24]}$, Maqbool et al. ${ }^{[25]}$ and Shabir et al. ${ }^{[26]}$ and also few reports carried out in regards to the autumn season for short listing of the breeds/ races/ hybrids for commercialization of the second crop in the temperate 
region of Kashmir (Malik et al. ${ }^{[5,7,27]}$ and Nooruldin et al. ${ }^{[28]}$, Shivkumar et al. ${ }^{[29]}$ and Shivkumar et al. ${ }^{[30]}$.

Hence, under the present research study, the lines identified (line-1, line-5, line-6, line-7, line-9, line-16, line-17, and line-18) have shown superior in performance at F9 generation can conveniently be utilized for developing high yielding autumn specific bivoltine stable breeds/hybrids. Further, after passing through proper test trials for the identified eight lines/breeds to check out its feasibility/stability to withstand at temperate climatic condition can conveniently be used for commercial exploitation at farmer's level during the autumn season in the temperate climatic condition of Jammu and Kashmir.

\section{CONCLUSIONS}

The present findings evaluated based on multi-traits E.I demonstrated that the eight (08) autumn specific breeding lines explained above expressed more favourable at F9 generation. Further, based on the E.I values of all the 18 lines revealed different values for $E . I$ and it is needless to say that, the 08 lines viz., line-1, line5 , line-6, line-7, line-9, line-16, line- 17 and line-18 with $>50$ evaluation index values have shown significant influence on the expression of qualitative and quantitative traits and have economic importance under the study. Hence, obtained results from the study will conveniently be utilized for selecting best-breeding lines for evolving lines for the autumn season, conveniently be utilized for developing high yielding autumn specific bivoltine hybrids and can be used for commercial exploitation at farmer's level during the autumn in temperate climatic conditions of the Jammu and Kashmir.

\section{ACKNOWLEDGMENTS}

Authors wish to express the deep sense of gratitude to the Central Silk Board and Central Sericultural Research and Training Institute, Pampore, Jammu and Kashmir for facilitating to carrying out this research programme under the project AIB-3570.

\section{CONTRIBUTION OF AUTHORS}

Research concept- Shivkumar

Research design- Shivkumar

Supervision- Mir Nisar Ahmad

Materials- Shivkumar
Data collection- Shivkumar, Bharath Kumar Neelaboina, Kiran R

Data analysis and interpretation- Shivkumar, Mir Nisar Ahmad

Literature search- Shivkumar, Bharath Kumar Neelaboina, Kiran $\mathrm{R}$

Writing article- Shivkumar

Critical review- Mir Nisar Ahmad

Article editing- Shivkumar, Mir Nisar Ahmad

Final approval- S Roy Chowdhury

\section{REFERENCES}

[1] Sahaf KA, Bhat SA, Mir Nissar. Sericulture in Northwest India with special reference to temperate region- problems and prospects. National seminar on sericulture development in temperate regionproblems and prospects, 2016; 34-38.

[2] Trag AR, Kamili AS, Malik GN, Kukiloo FA. Evolution of high yielding bivoltine silkworm, Bombyx mori genotypes. Sericologia., 1992; 32: 321-24.

[3] Kamili AS. New bivoltine silkworm breeds and their hybrids (SKAU-HR-1) Technical Document. Sher-eKashmir University of Agricultural Sciences and Technology of Kashmir (J \& K), 1996.

[4] Malik GN, Rufaie SZ, Baqual MF, Kamilli AS, Dar HU. Comparative performance of some bivoltine silkworm, Bombyx mori L. hybrids. Entomon., 2006; 1: 61-64.

[5] Malik MA, Kamilli AS, Sofi AM, Malik GN, Sabahat A, et al. Evaluation and identification of region/season specific bivoltine hybrids of the silkworm, Bombyx mori L. suitable for Kashmir climatic conditions. J Expt Zool India, 2010; 13: 171-76.

[6] Farooq M, Singh TP, Nooruddin, Rufaie ZH, Baqual M, et al. Second commercial crop to make sericulture a more profitable in Kashmir. Proceedings of regional Seminar on Prospects and Problems of Sericulture as are economic enterprise in North West India, 2006; 275-76.

[7] Malik MA, Kamili AS, Sofi AM, Malik GN, Sabahat A, et al. Second commercial silkworm rearing in Kashmir- A ray of hope, Indian Silk, 2009; 9: 10-11.

[8] Nisar M, Chishti MZ, Khan MA. Studies on the identification of summer specific silkworm Bombyx mori $\mathrm{L}$ hybrids under temperate climatic conditions of Jammu and Kashmir, India JIARM, 2013; 1(3): 1-10. 
[9] Chauhan TPS, Singh RD, Mukesh T, Anil D. Sericulture in North India; Consolidation of approaches. Indian Silk, 2008; 47(5): 14-16.

[10]Gamo T. On concepts and trends in silkworm breeding. Farming Japan, 1976; 10(6): 11-12.

[11]Harada C. On the heterosis of qualitative characters in the silkworms, Bull Seric Exp Stn., 1961; 17(1): 152.

[12]Toyama K. Breeding methods of silkworm. Jap. Sangyo Shimpo., 1906; 158: 282-86.

[13]Yokoyama T. Silkworm selection and hybridization. In: Genetics in relation to insect management. Working papers. The rockfeller Foundation, 1979; 71-83.

[14]Tazima Y. The Silkworm an important laboratory tool. National Institute of Genetics Kodansha, Tokyo, Japan, 1978.

[15]Krishnaswami S. Improved methods of rearing young age (Chawki) silkworms. CSRTI Mysore Bull., 1978; 3: 1-27.

[16]Mano Y, Nirmal Kumar S, Basavaraju HK, Mal Reddy $\mathrm{N}$, et al. A new method to select the promising silkworm breeds/ combinations. Indian silk, 1993; 31(10): 53.

[17]Perkins JM, Jink JL. Environmental and genotypeenvironmental components of variability III. Multiple lines and crosses. Heredity, 1968; 23: 339-56.

[18]Sengupta K. An analysis of genotype environment interaction in some races of silkworm, Bombyx mori L. Indian J Seric., 1969; 8 (1): 4-6.

[19]Freeman GH, Perkins JM. Environmental and genotype-environmental components of variability VIII. Relations between genotypes grown in different environments and measures of these environments. Heredity, 1971; 27: 15-23.

[20]Krishnaswami S, Narasimhanna MN. Large scale trials of bivoltine hybrids in Mysore state. Ind. J Genet \& PI Breed, 1974; 34(A): 229-36.

[21]Subramanya G, Murakami A. Climatic differential phenotypic expression of voltine genes in Bombyx mori. Ind J Seric., 1995; 33(2): 103-09.
[22]Anantha R, Subramanya G. Differential expression of quantitative traits in multivoltine races and bivoltine breeds of the silkworm Bombyx mori L. The Bioscan., 2010; 5(1): 35-40.

[23]Shiv K, Subramanya G. Studies on the evaluation index for selected quantitative characters in silkworm races and mutants of Bombyx mori L. Mysci., 2010; 2: 32-43.

[24]Masrat B, Afifa S. Kamili, Sharma RK. Influence of seasonal variation on cocoon, silk filament and economic traits of Bombyx mori L. Internl J Adv Biol Res., 2014; 4(3): 362-68.

[25]Maqbool A, Dar HU, Ahmad M, Malik GN, Zaffar G, et al. Comparative performance of some bivoltine silkworm (Bombyx mori L.) genotypes during different seasons. Acad J., 2015; 10(12): 407-10.

[26]Shabir A Bhat, Malik Farooq IL Khan, Sahaf KA. Studies on the performance of some silkworm, Bombyx mori L, hybrids during summer season in Kashmir, J Entom Zool Stu., 2017; 5(5): 1346-48.

[27]Malik MA, Sofi AM, Malik GN, Kamilli AS, Sabahat A, et al. Identification of autumn specific breeding resource material of Bombyx mori L. suitable for second commercial rearing under Kashmir climatic conditions. J Expt Zool India, 2010a; 13: 139-42.

[28]Nooruldin S, Bhat SA, Malik MA, Khan IL, Sahaf KA. Comparative performance of some silkworm hybrids during different seasons under Kashmir climatic conditions. Green Farming, 2015; 6(6): 1392-95.

[29]Shiv K, Bharath KN, Mir NA, Shakeel A, Ravindra MA, et al. Studies on improvement of quantitative traits of the silkworm, Bombyx mori L. during autumn under temperate climatic conditions of Kashmir., J Entom Zool Stu., 2018; 6(4): 677-82.

[30]Shiv K, Bharath KN, Mir NA, Chowdhury SR. Development of autumn specific potential and high yielding silkworm (Bombyx mori L.) breeds and hybrids for temperate climate in Jammu \& Kashmir, Res J Agric Sci., 2020; 11(1): 62-67. 